Running head: PEDAGOGICAL QUESTIONS IN CHILDES

\title{
Pedagogical Questions in Parent-Child Conversations
}

Yue Yu² (yue.yu@ rutgers.edu), Elizabeth Bonawitz² (elizabeth.bonawitz@ rutgers.edu), Patrick Shafto ${ }^{1}$ (patrick.shafto@gmail.com)

Department of ${ }^{1}$ Math and Computer Science \& ${ }^{2}$ Psychology, Rutgers University - Newark

Author Note

This study is supported by NSF CAREER, DRL-1149116 to P.S and NSF Award SMA1640816 to E.B. and P.S. We thank Reham Bader, Jack Fredricks, Victoria Golinski and Rosa Lasso for coding. We thank four anonymous reviewers for providing constructive comments and suggestions. Correspondence concerning this article should be addressed to Yue Yu, Department of Mathematics \& Computer Science, Rutgers University-Newark, NJ 14850. Email: yue.yu@ rutgers.edu.

Word Count: 5888 


\begin{abstract}
Questioning is a core component of formal pedagogy. Parents commonly question children, but do they use questions to teach? Here we define "pedagogical questions" as questions for which the questioner already knows the answer and intended to help the questionee learn. We investigate the frequency and distribution of pedagogical questions from parent-child conversations documented in the CHILDES database. By analyzing 2166 questions from 166 mother-child dyads and 64 father-child dyads, we find that pedagogical questions are commonplace during day-to-day parent-child conversations, and vary based on child's age, family environment, and historical era. The results serve as a first step towards understanding the role of parent-child questions in facilitating children's learning.
\end{abstract}

Keywords: informal pedagogy, pedagogical questions, parent-child conversation, socioeconomic status, CHILDES. 


\section{Pedagogical Questions in Parent-Child Conversations}

To question well is to teach well.

- Henry Barnard, 1860, American Journal of Education

Asking and answering questions has been seen as a core component of teaching and learning at least since the days of Socrates. Teachers ask $~ 400$ questions per day in a typical classroom setting (Gall, 1970), serving various functions from checking class work to motivating thinking (Black, 2001). Research in education suggests that questioning leads to improvements in academic outcomes (Redfield \& Rousseau, 1981; Von Secker, 2002; Wise \& Okey, 1983). Research in cognitive development has shown that parents engage in question-asking throughout childhood (Ervin-Tripp \& Miller, 1977), starting by at least as early as five-months-old (Bornstein et al., 1992). Questions seem to support language learning (Blewitt, Rump, Shealy, \& Cook, 2009; Sénéchal, 1997) as well as general content learning (Haden, Cohen, Uttal, \& Marcus, 2015). Thus, past research has demonstrated that questions are both ubiquitous in early childhood and also a potential key to children's learning and development.

However, for a learner, not all questions are created equal. Research has estimated that around $80 \%$ of questions asked in classrooms are for teaching (Gall, 1970), among them a majority are prompts for facts and a minority are prompts to elicit thinking (Siraj-Blatchford \& Manni, 2008). These questions by a (presumably) knowledgeable teacher to the less knowledgeable learners are unusual relative to the kinds of questions we most commonly think about in day-to-day conversation. Most commonly, questions are a tool for eliciting information from others ("information-seeking questions") or to make a point ("rhetorical questions") (Searle, 1969; Shatz, 1978). However, "pedagogical questions"-questions that are asked by a knowledgeable individual whose goal is teaching — are unique from other kinds of questions. 
Whereas information-seeking questions are asked to elicit unknown information from the questionee, and rhetorical questions are questions to which both or neither of the parties know the answer, pedagogical questions are questions asked by the person who knows the answer (or might reasonably expected to know the answer) to someone who may not know the answer, with the goal of eliciting learning.

Do parents employ pedagogical questions? We know that parent-child conversation plays a vital role in facilitating children's thinking and learning (Crowley et al., 2001; Frazier, Gelman, \& Wellman, 2009), and questioning is prevalent in parental discourse from early on in development (Bornstein et al., 1992; Kurkul \& Corriveau, in press). Therefore, it becomes important to ask whether pedagogical questions are commonplace. Previous functional and syntactic categorizations of questions have identified types of questions that may relate to facilitating learning, such as $w h$ - questions, open-ended questions, test questions, and knowledge questions (Bloom, Engelhart, Furst, Hill, \& Krathwohl, 1956; Chouinard, Harris, \& Maratsos, 2007; Ervin-Tripp, 1970; Olsen-Fulero \& Conforti, 1983; Rowe, Leech, \& Cabrera, 2016; Shatz, 1979). However, none of these categories accurately capture the essence of questions used for teaching. For example, wh- and open-ended can be used to seek information from children (e.g., “What do you want to play?"), whereas test and knowledge questions can be used to check children's memory without trying to teach new information (e.g., "Do you remember that?"). Therefore, in this paper we take a new perspective and analyze parent-child questions by focusing on the knowledge state and the intention of the parent.

\section{Pedagogical questions support learning}

Theories on informal pedagogy (Csibra \& Gergely, 2009; Tomasello, 1999) may help us understand how parents help children learn through informal instruction. Infants and young 
children are sensitive to cues that suggest an adult's intention to teach, such as joint attention, child-directed speech, name-calling, etc. (Csibra \& Gergely, 2009). Older children also consider whether the teacher is knowledgeable when drawing inferences in teaching contexts (Bonawitz et al., 2011; Gonzalez, Shafto, Bonawitz, \& Gopnik, 2012; Harris \& Corriveau, 2011; Koenig, Clément, \& Harris, 2004; Shafto, Goodman, \& Frank, 2012). These “pedagogical cues" engage strong inferences, which facilitates learning in various domains (Bonawitz et al., 2011; Buchsbaum, Gopnik, Griffiths, \& Shafto, 2011; Butler \& Markman, 2014; Nielsen, 2006; Sage \& Baldwin, 2010; Topál, Gergely, Miklósi, Erdőhegyi, \& Csibra, 2008; Vredenburgh, Kushnir, \& Casasola, 2014).

Like pedagogical instruction, pedagogical questions imply an opportunity for learning for the questionee. An ignorant person asking "What does that button do?" is likely simply seeking information about the button. However, when the exact same question is asked by a person who is assumed to already know the answer, more can be inferred by the questionee: The questioner is probably trying to convey something worth learning about the button. Our recent experiments have shown that when presented with a novel toy, 4- and 5-year-old children indeed learned and explored more after being asked "What does the button do?" from a knowledgeable teacher, rather than after being asked the exact same question from an ignorant bystander (Yu, Landrum, Bonawitz, \& Shafto, under review). Children also take the knowledge state of a questioner into account when deciding whether to revise a previously stated belief (Bonawitz et al., under review). Additionally, children assume that a teacher, but not a bystander, will ask them about something the questioner already knows: When an adult asked "Where is X?" during an ongoing pedagogical interaction with a 2-year-old, the toddler was more likely to assume that " $\mathrm{X}$ " referred to an object known to the adult and the adult was trying to draw her attention to that 
object; whereas when an adult asked "Where is X?" while doing things alone, the toddler was more likely to assume that " $X$ " referred to an object unknown to the adult and the adult is searching for that object (Grosse \& Tomasello, 2012). These findings suggest that young children associate the knowledge state of a questioner with his or her pedagogical intent, which has implications for their learning.

Pedagogical questions may also differ from pedagogical instructions in important ways: While pedagogical instructions facilitate learning of what is being instructed, they also elicit the learner's inference that the teacher is purposefully choosing what to instruct and not to instruct, so what is not chosen is probably unimportant and need not be explored (Shafto, Goodman, \& Griffiths, 2014). These inferences have been shown to lead to less exploration and further learning when the environment afford more learning opportunities than what was instructed (Bonawitz et al., 2011; Shneidman, Gweon, Schulz, \& Woodward, 2016). However, the constraints on exploration and further learning is not observed when pedagogical instructions are reframed as pedagogical questions (Yu et al., under review), suggesting that the choice of pedagogical method has implications on children's learning.

\section{Contextual factors}

Several factors might influence the use of pedagogical questions. For example, past research has found that the type of questions parents ask children changes with children's age (Kuchirko, Tamis-LeMonda, Luo, \& Liang, 2015; Snow et al., 1976). Previous studies have also identified differences between mother-child and father-child conversations (Gleason, 1975; Rowe, Coker, \& Pan, 2004; Walker \& Armstrong, 1995), as well as an effect of father's presence on motherchild interaction (Clarke-Stewart, 1978). Therefore, in our analysis we included children's age and the presence of mothers and fathers as possible predictors of questioning behavior. 
Pedagogy also varies across culture and time (Shneidman, Gaskins, \& Woodward, 2015), and the types of questions parents ask children differ based on family environment (Hoff, 2003; Snow et al., 1976). For example, during free play, mothers from academic middle-class families posed more wh-questions and less yes-no questions than mothers from working-class and lower middle-class families (Snow et al., 1976), and the use of wh-questions in father-child interactions were shown to predict children's language development in low-income families (Rowe et al., 2016). Based on these findings, we have included family socioeconomic status (SES) as well as location and time of data collection as possible predictors of questioning behavior.

\section{CHILDES Analyses}

To address whether and how parents use pedagogical questions, we analyzed parent-child conversations from the CHILDES database (MacWhinney \& Snow, 1990). We coded parents' spontaneous child-directed questions into three categories: Pedagogical questions are those for which parents know the answer and want children to learn; information-seeking questions are those for which parents do not know the answer and seek the answer from the child; and rhetorical questions are those not intend to be answered, either because there is no obvious answer or because it is assumed that both parties already know the answer. We also recorded parents' gender, child's age and gender, context of the conversation, measurements of family environment, and time and location of data collection, so as to examine how parents' questioning behavior may vary based on these factors.

\section{Method}

\section{Sample}

We searched the entire CHILDES database (MacWhinney \& Snow, 1990) for transcripts that meet the following nine criteria: 
1. The transcript was in English.

2. The conversation took place at home.

3. At least one parent and one child participated in the conversation, and no one outside the immediate family (interviewer, grandparents, relatives, friends, etc.) was involved.

4. The target child was between 2 and 6 years of age.

5. The conversation represented everyday talk, and was not a purposeful conversation such as an interview.

6. The transcripts for parents' and child's speech were not separated.

7. The transcript used punctuation marks.

8. The transcript contained at least three questions between a parent and a child.

9. If there were multiple transcripts for a same parent-child dyad (such as in longitudinal studies), we only used the first (earliest) transcript that meets all other criteria.

According to these criteria, 185 transcripts were collected from 27 studies, which included 166 mother-child conversation samples and 64 father-child conversation samples (Figure 1). Detailed information for each study is listed in Table 1. For each study, we recorded the time and location of data collection. Because detailed information on data collection was not available for all studies, we specified time at the level of decade (1970s, 1980s, 1990s, 2000s), and specified location at the level of country (USA, UK). We recorded family SES for studies that reported a homogenous sample (e.g., all participants were from working-class or middle-class families), and for studies that specified SES for each individual family. We did not record SES if the study only reported SES of the neighborhood from which the families were recruited, but did not report SES of the actual families that participated. Whenever possible, we also recorded sampling and procedural information to control for possible differences across studies. These include whether 
the study used random sampling or convenience sampling (e.g., researcher's own child), number of children we included from the study, the settings of the recordings, the instructions given to the parents, and the length of recording (Table 1). Two of these factors — sampling method of the study and the number of children we included from the study-were easy to quantify and were available for all studies, so we added them as study-level control variables in our statistical analyses. Neither predicted parents' questioning behavior or changed the significance of other predictors (Table 3).

\section{Coding Procedures}

Step-by-step coding instructions and the training process of the coders are detailed in the Supplementary Material. For each transcript, one coder first recorded the target child's gender, age, and the conversation partners from the heading of the transcript. The coder then derived the total number of the parent's statements and questions in the transcript using CLAN, the programming tool provided by the database (MacWhinney, 2000). The frequency of questioning (per 100 statements) was calculated by dividing the number of questions by the total number of statements, and then multiplying by 100 .

Following the recording of this initial information, two coders who were blind of the hypotheses independently coded the first 10 questions that 1) ended with a question mark; 2)

were asked by the parent; 3) were directed towards the target child; and 4) did not contain missing words. Out of the 230 conversation samples, 30 contained less than 10 such questions (with a minimum of 3 questions), and for those transcripts all questions were coded. Each question was coded according to the coding scheme listed in Table 2: The coders first determined whether the question was a pedagogical question, information-seeking question, or rhetorical question based on the knowledge state and the intention of questioner. They then 
assigned the questions into one of eight subcategories: The pedagogical questions were further distinguished based on whether they were intended to teach generic or specific knowledge (Gelman, Goetz, Sarnecka, \& Flukes, 2008), and the information-seeking and rhetorical questions were further distinguished based on their functions (Olsen-Fulero \& Conforti, 1983). In cases when parent's knowledge state and intention were difficult to judge by the question itself, coders would then refer to 1) contexts before and after the question, 2) the linked audio or video clips if they were available. Since transcripts do not fully capture the history and nonverbal aspects in parent-child interactions, and audio or video clips were not always available, some questions could remain ambiguous despite coders' best effort. In Supplementary Material we provided an estimation of the frequency of these ambiguous situations, and explained why they should have limited impact on our final results. Overall the inter-rater reliability was high, which shows the majority of questions can be reliably categorized based on our coding scheme: When only the three major categories were considered, Cohen's $\kappa=.830$; When all eight subcategories were considered, Cohen's $\kappa=.832$. Inconsistent codes were reviewed and resolved by a third coder.

To ensure that questions for which parents knew the answer of were indeed pedagogical, a fourth independent coder (who was not involved in the initial coding, but familiar with research on informal pedagogy) checked a subsample of questions coded as pedagogical $(n=132)$ to see "if the questions can be interpreted as intended to teach, where teaching is broadly defined as any endeavor to help children learn". Among the 132 questions, 123 (93.2\%) were coded as clearly intended to teach, and the rest 9 questions (6.8\%) were ambiguous instances in which the parent may be intended to help the child learn, but the transcript did not provide enough context to accurately judge the parent's intentions. We take these findings as evidence that our coding of 
pedagogical questions indeed captured parents' pedagogical intent. Details of the procedure and results of this additional coding are described in the Supplementary Material.

For each question, the two initial coders also decided whether the child responded to the question (repeated the question or provided an answer), whether the parent followed-up the question (repeated the question, provided an answer, or added relevant information), or whether the next line is irrelevant (a different person spoke or the topic was changed). Inter-rater reliability was high (Cohen's $\kappa=.846$ ), and inconsistent codes were reviewed and resolved by the third coder.

After coding all 10 questions, the first two coders also determined whether the main context of the conversation was 1) over meal (lunch or dinner), 2) during free play (e.g., playing with toys, book reading, spontaneous play or talk), or 3) during daily routines (e.g., taking a bath, preparing to leave).

\section{Data analysis}

All data was entered and analyzed in IBM SPSS 22. Given the multilevel structure of our sample (parent-child dyads were nested under studies), we used multilevel mixed-effects linear regression models as the analytical tool for omnibus tests (advantages of using multilevel models to analyze archival data are detailed in the Supplementary Material). Fisher's exact test was used for comparisons of frequencies. An $\alpha$ level of .05 (two-tailed) was used for all tests.

\section{Results}

Table 2 shows the average proportion of each category and subcategory of questions in mother-child and father-child conversations. Mothers and fathers did not differ in the proportion of pedagogical and information-seeking questions they asked, although there were differences in rhetorical questions and subcategories of information-seeking questions (Table 2). To examine 
the contributing factors to parents' questioning behavior, we started with a multilevel model that includes all conversation-level, child-level, and study-level predictors as independent variables, to predict the proportion of pedagogical questions (Table 3, Model 1). Results showed that the child's age, the SES of the family, and the time of data collection had significant effects on parents' pedagogical questions towards children. We then reduced Model 1 by excluding all nonsignificant predictors. The revised model (Model 2) was superior to Model 1 by the criterion of restricted log likelihood and Bayesian Information Criterion (Table 3), and was robust when cross-validation was applied (details see Supplementary Material).

Model 2 showed that the proportion of pedagogical questions decreased with children's age (Figure 2), $B=-.004, p=.038$. Parents asked a larger proportion of pedagogical questions to toddlers (24-36 months; $n=72 ; M=34 \%)$ than to preschoolers $(36-72$ months; $n=94 ; M=$ $25 \%), t(179.4)=2.43, p=.016, d=0.33$. When we separated subcategories of generic and specific pedagogical questions, the age trend was significant for the generic questions, $B=-.004$, $p<.001$, but not the specific questions, $B=.000, p=.86$. Additionally, the proportion of pedagogical questions was higher in families noted as middle-class $(n=30 ; M=55 \%)$ than in families noted as working-class $(n=85 ; M=19 \%), B=.261, p=.003$, and this was true for the specific questions, $B=.245, p=.007$, but not general questions, $B=.028, p=.57$. Finally, the proportion of pedagogical questions increased with historical era, $B=.063, p=.038$, with parents from the 2000s asking a larger proportion of pedagogical questions $(n=14 ; M=42 \%)$ than parents from the $1970 \mathrm{~s}(n=64 ; M=26 \%), t(76)=2.30, p=.024, d=0.68$. Again, this was true for the specific questions, $B=.056, p=.030$, but not general questions, $B=.008, p=.63$. Further analysis showed no significant two-way interaction effects between child's age, SES, and historical era. 
To examine whether child's age, SES, and historical era also have an impact on the other types of questions, we applied Model 2 to the proportion of information-seeking and rhetorical questions, as well as parents' overall frequency of questions (per 100 statements). Results showed that the proportion of information-seeking questions increased with children's age, $B$ $=.005, p=.007$, and decreased with historical era, $B=-.070, p=.032$. The proportions of information-seeking and rhetorical questions were also lower in middle-class families than in working-class families (Figure 3), $B \mathrm{~s}<-0.110, p \mathrm{~s}<.066$. The overall frequency of questions (per 100 statements) was not predicted by child's age or historical era, $p \mathrm{~s}>.32$, but it was higher for middle-class parents compared to working-class parents, $B=.137, p=.011$. To examine if the difference in overall frequency of questions is responsible for the different proportions of question types observed between middle-class and working-class families, we estimated the frequencies of different question types by multiplying the proportion of the question types by the overall frequency of questions. According to this estimate, middle-class parents asked pedagogical questions more frequently than working-class parents, $B=.107, p=.011$, and the frequency of information-seeking and rhetorical questions did not differ between middle-class and working-class parents, $B \mathrm{~s}<.017, p \mathrm{~s}>.29$. Therefore, the higher proportion of pedagogical questions in middle-class families was driven by higher frequencies of these questions, and not by lower frequencies of information-seeking or rhetorical questions.

We further examined whether the same predictors are associated with mothers' and fathers' questioning. The proportion of mothers' pedagogical questions decreased with age, $B=-.005, p$ $=.009$, but age was not a significant predictor for fathers' pedagogical questions, $B=.001, p$ $=.85$ (Figure 2). SES is strongly associated with both mothers' and fathers' questions: Middleclass mothers and fathers asked a higher proportion of pedagogical questions than working-class 
mothers and fathers, $t \mathrm{~s}>43.02, p \mathrm{~s}<.001$ (Figure 3). Mothers' pedagogical questions increased with historical era, $B=.054, p=.049$, with mothers from the 2000 s asking a higher proportion of pedagogical questions than mothers from the 1970s and 1980s, $t \mathrm{~s}>2, p \mathrm{~s}<.05, d \mathrm{~s}>0.7$. Fathers' pedagogical questions also show an increasing trend with historical era (Figure 4), although the trend was non-significant, $B=.045, p=.12$. Finally, an interaction effect between parents' gender and the presence of other parent was observed for the proportion of pedagogical questions, $F(1,226)=4.36, p=.038$ (Figure 5). Mothers asked more pedagogical questions when a father is noted as present compared to not present, $B=.083, p=.045$, but fathers' pedagogical questions did not differ based on mothers' presence, $B=-.172, p=.17$.

To better understand the nature of parents' pedagogical questions, we also looked at the responses and follow-ups of these questions. Here the follow-up is defined as a relevant statement immediately after the initial question, and can be a repeat of the question, an answer to the question, or the addition of question-relevant information. Overall children responded to a similar proportion of pedagogical questions (47\%) and information-seeking questions (46\%), Fisher's exact $p=.70$. However, parents were more likely to follow-up a pedagogical question $(23 \%)$ than an information-seeking question $(17 \%, p=.004)$ or a rhetorical question $(16 \%, p$ $=.043)$. Parents were also more likely to follow-up pedagogical questions for toddlers $(26 \%)$ than for preschoolers $(19 \%), p=.036$, despite that both toddlers $(45 \%)$ and preschoolers $(49 \%)$ responded to a same amount of pedagogical questions, $p=.34$. These results suggest that pedagogical questions are different in kind from information-seeking or rhetorical questions: They involve greater degrees of interaction between parent and child, which appear to reflect differences in parents' behavior rather than children's responsiveness.

\section{Discussion}


Educators use questions for which they already know the answer to guide students' learning. Our results suggest that parents do as well. Moreover, the proportion of pedagogical questions parents ask their children varies based on several factors, including children's age, family SES, and the historical era. Mothers' tendencies to ask pedagogical questions also differed based on whether a father is present during the conversation.

The finding that parents' pedagogical questioning differed by children's age is consistent with previous research showing that parents adjust utterance in general (Snow, 1972), and questions in particular (Kuchirko et al., 2015), with regard to the age of their children. Specifically, we have shown that the proportion of pedagogical questions, especially those asking about general kinds, was higher in parents' questions towards their toddlers than their preschoolers. These developmental changes, together with evidence that American mothers ask pedagogical questions even to 5-month-old infants (Bornstein et al., 1992), may shed light on the nature of pedagogical questions. First, parents' use of questions to teach, and the benefits it brings to children's learning, may occur well before children can understand or answer these questions. Indeed, research has shown that even infants could be sensitive to others' pedagogical intent and knowledge states (Csibra \& Gergely, 2009; O'Neill, 1996), which raises the possibility that pedagogical questions could help drive infants' attention and serve as language input without the expectation of being answered verbally. Acoustic features like interrogative prosody have been suggested to serve as a cue to facilitate learning (Bornstein \& Lamb, 2002), raising a potentially relevant avenue for understanding the mechanism behind how early pedagogical questioning are used to teach. Second, the decreasing trend of parents' pedagogical questioning from toddlerhood to preschool years is in contrary to children's increasing abilities and needs to learn. It is possible that parents are changing tools to stir learning-older children may require 
fewer pedagogical cues to indicate an opportunity to learn, so parents may switch to more direct forms of teaching. It is also possible that because of an increasing ability to respond to information-seeking questions, older children are asked more information-seeking questions instead of pedagogical questions.

Consistent with previous studies (e.g., Clarke-Stewart, 1978; Hoff, 2003; Snow et al., 1976), we show that family environment plays a major role in how parents ask children questions. Mothers and fathers from working-class families ask less than half as many pedagogical questions as mothers and fathers from middle-class families. Additionally, mothers also ask more pedagogical questions when a father is present. Further research is needed to identify the family dynamics underlying question asking in different social groups, and their implications on children's learning and school readiness. Nonetheless, the current results add to a growing body of research suggesting the importance of examining the quality of parent-child interactions, over and above quantity, on children's cognitive development (Hirsh-Pasek et al., 2015).

Finally, we found parents' questioning practices to change over recent history, with millennial mothers asking significantly more pedagogical questions than mothers from the 1970s and 80s. This effect may be related to the historical trend of parents becoming older and more educated (Pew Research Center, 2010). It points to the importance of situating research in the historical contexts when studying parenting practices in general, and questioning behavior in particular.

The sample for our study comes from the CHILDES database, so the scope is limited to information made available, and for the available variables the data were not balanced. Randomassignment experiments are needed to confirm our findings, and to extend them to cover other important factors. For example, although we did not find differences in questioning between 
parents from USA and UK, these results may not hold universally. In fact, mothers from western societies may be unique in their strong tendencies to ask questions to infants (Bornstein \& Lamb, 2002), so future study need to verify the results in other cultures.

In conclusion, this study builds upon and extends an accumulating literature on the role of informal pedagogy in children's learning. Parents may teach not only through direct instruction, but also through asking questions for which they know the answer. Our results suggest that parents do consistently use pedagogical questions in their day-to-day conversations, and the relative frequencies of these questions depend on children's age, family environment, and historical context. A critical next step, then, is to evaluate children's inferences from, and learning outcomes following, pedagogical questions. Doing so will help bridge theories of pedagogy and inquiry-based learning, and bring us closer to understanding how to question well. 


\section{References}

Black, S. (2001). Ask me a question: How teachers use inquiry in a classroom. American School Board Journal, 188(5), 43-45.

Blewitt, P., Rump, K. M., Shealy, S. E., \& Cook, S. A. (2009). Shared book reading: When and how questions affect young children's word learning. Journal of Educational Psychology, 101(2), 294-304. doi:10.1037/a0013844

Bloom, B. S., Engelhart, M. D., Furst, E. J., Hill, W. H., \& Krathwohl, D. R. (1956). Taxonomy of educational objectives, handbook I: The cognitive domain. New York: David McKay Co Inc.

Bohannon III, J. N., \& Marquis, A. L. (1977). Children's control of adult speech. Child Development, 48(3), 1002-1008. doi:10.2307/1128352

Bonawitz, E., Shafto, P., Gweon, H., Goodman, N. D., Spelke, E., \& Schulz, L. (2011). The double-edged sword of pedagogy: Instruction limits spontaneous exploration and discovery. Cognition, 120(3), 322-330. doi:10.1016/j.cognition.2010.10.001

Bonawitz, E., Shafto, P., Yu, Y., Gonzalez, A., Bridgers, S., \& Gopnik, A. (under review). Children change their answers in response to neutral follow-up questions by a knowledgeable asker.

Bornstein, M. H., \& Lamb, M. E. (2002). Development in infancy: An introduction. New York: McGraw-Hill.

Bornstein, M. H., Tal, J., Rahn, C., Galperin, C. Z., Pêcheux, M.-G., Lamour, M., ... TamisLeMonda, C. S. (1992). Functional analysis of the contents of maternal speech to infants of 5 and 13 months in four cultures: Argentina, France, Japan, and the United States. Developmental Psychology, 28(4), 593. doi:10.1037/0012-1649.28.4.593 
Braunwald, S. R. (1976). Mother-child communication: The function of maternal-language input. In R. Von Raffler-Engel (Ed.), Child language-1975 (pp. 28-50). Great Britain: International Linguistics Association.

Buchsbaum, D., Gopnik, A., Griffiths, T. L., \& Shafto, P. (2011). Children's imitation of causal action sequences is influenced by statistical and pedagogical evidence. Cognition, 120(3), 331-340. doi:10.1016/j.cognition.2010.12.001

Butler, L. P., \& Markman, E. M. (2014). Preschoolers use pedagogical cues to guide radical reorganization of category knowledge. Cognition, 130(1), 116-127. doi:10.1016/j.cognition.2013.10.002

Chouinard, M. M., Harris, P. L., \& Maratsos, M. P. (2007). Children's questions: A mechanism for cognitive development. Monographs of the Society for Research in Child Development, i-129.

Clarke-Stewart, K. A. (1978). And daddy makes three: The father's impact on mother and young child. Child Development, 466-478.

Crowley, K., Callanan, M. A., Jipson, J. L., Galco, J., Topping, K., \& Shrager, J. (2001). Shared scientific thinking in everyday parent-child activity. Science Education, 85(6), 712-732.

Csibra, G., \& Gergely, G. (2009). Natural pedagogy. Trends in Cognitive Sciences, 13(4), 148153. doi:10.1016/j.tics.2009.01.005

Demetras, M. (1986). Working parents' conversational responses to their two-year-old sons. University of Arizona.

Demetras, M. (1989). Changes in parents' conversational responses: A function of grammatical development. Paper presented at the ASHA, St. Louis, MO.

Demetras, M., Post, K. N., \& Snow, C. E. (1986). Feedback to first language learners: The role 
of repetitions and clarification questions. Journal of Child Language, 13(02), 275-292. doi:10.1017/S0305000900008059

Demuth, K., Culbertson, J., \& Alter, J. (2006). Word-minimality, epenthesis and coda licensing in the early acquisition of English. Language and Speech, 49(2), 137-173. doi:10.1177/00238309060490020201

Dickinson, D. K., \& Tabors, P. O. (2001). Beginning literacy with language: Young children learning at home and school. Baltimore: Paul Brookes Publishing.

Ervin-Tripp, S. (1970). Discourse agreement: How children answer questions. Cognition and the development of language, 79-107.

Ervin-Tripp, S., \& Miller, W. (1977). Early discourse: Some questions about questions. In M. M. Lewis \& L. A. Rosenblum (Eds.), Interaction, conversation, and the development of language. New York: Wiley.

Feldman, A., \& Menn, L. (2003). Up close and personal: A case study of the development of three English fillers. Journal of Child Language, 30(04), 735-768. doi:10.1017/S0305000903005774

Frazier, B. N., Gelman, S. A., \& Wellman, H. M. (2009). Preschoolers'search for explanatory information within adult-child conversation. Child Development, 80(6), 1592-1611.

Gall, M. D. (1970). The use of questions in teaching. Review of Educational Research, 707-721.

Gelman, S. A., Goetz, P. J., Sarnecka, B. W., \& Flukes, J. (2008). Generic language in parentchild conversations. Language Learning and Development, 4(1), 1-31.

Gleason, J. B. (1975). Fathers and other strangers: Men's speech to young children. In D. P. Dato (Ed.), Developmental psycholinguistics: Theory and applications (pp. 289-297). Washington, DC: Georgetown University Press. 
Gleason, J. B. (1980). The acquisition of social speech: Routines and politeness formulas. In H. Giles, W. Robinson, \& P. Smith (Eds.), Language: Social psychological perspectives (pp. 159-167). Oxford, UK: Pergamon.

Gonzalez, A., Shafto, P., Bonawitz, E., \& Gopnik, A. (2012). Is that your final answer? The effects of neutral queries on children's choices. Proceedings of the thirty-fourth cognitive science society.

Grosse, G., \& Tomasello, M. (2012). Two-year-old children differentiate test questions from genuine questions. Journal of Child Language, 39(01), 192-204.

Haden, C. A., Cohen, T., Uttal, D. H., \& Marcus, M. (2015). Building learning: Narrating and transferring experiences in a children's museum. In D. Sobel \& J. Jipson (Eds.), Cognitive Development in Museum Settings: Relating Research and Practice (pp. 84-103). New York, NY: Routledge.

Harris, P. L., \& Corriveau, K. H. (2011). Young children's selective trust in informants. Philosophical Transactions of the Royal Society B: Biological Sciences, 366(1567), 11791187. doi:10.1098/rstb.2010.0321

Hayes, D. P., \& Ahrens, M. G. (1988). Vocabulary simplification for children: A special case of 'motherese'? Journal of Child Language, 15(2), 395-410. doi:10.1017/S0305000900012411

Henry, A. (1995). Belfast English and Standard English: Dialect variation and parameter setting. New York: Oxford University Press.

Hirsh-Pasek, K., Adamson, L. B., Bakeman, R., Owen, M. T., Golinkoff, R. M., Pace, A., ... . Suma, K. (2015). The contribution of early communication quality to low-income children's language success. Psychological Science, 0956797615581493. 
Hoff, E. (2003). The specificity of environmental influence: Socioeconomic status affects early vocabulary development via maternal speech. Child Development, 74(5), 1368-1378.

Howe, C. (1981). Acquiring language in a conversational context. New York: Academic Press.

Koenig, M. A., Clément, F., \& Harris, P. L. (2004). Trust in testimony: Children's use of true and false statements. Psychological Science, 15(10), 694-698. doi:10.1111/j.09567976.2004.00742.x

Kuchirko, Y., Tamis-LeMonda, C. S., Luo, R., \& Liang, E. (2015). 'What happened next?': Developmental changes in mothers' questions to children. Journal of Early Childhood Literacy, 1468798415598822.

Kuczaj, S. A. (1977). The acquisition of regular and irregular past tense forms. Journal of Verbal Learning and Verbal Behavior, 16(5), 589-600. doi:10.1016/S0022-5371(77)80021-2

Kurkul, K. E., \& Corriveau, K. H. (in press). Question, explanation, follow-up: A mechanism for learning from others? Child Development.

Lieven, E., Salomo, D., \& Tomasello, M. (2009). Two-year-old children's production of multiword utterances: A usage-based analysis. Cognitive Linguistics, 20(3), 481-507. doi:10.1515/COGL.2009.022

MacWhinney, B. (2000). The CHILDES project: Tools for analyzing talk (3 ed.). Mahwah, NJ: Lawrence Erlbaum Associates.

MacWhinney, B., \& Snow, C. (1990). The child language data exchange system: An update. Journal of Child Language, 17(02), 457-472. doi:10.1017/S0305000900013866

McCune, L., \& Vihman, M. M. (1987). Vocal Motor Schemes. Papers and Reports in Child Language Development, 26, 72-79.

Nelson, K. (1989). Narratives from the crib. Cambridge, MA: Harvard University Press. 
Nielsen, M. (2006). Copying actions and copying outcomes: Social learning through the second year. Developmental Psychology, 42(3), 555-565. doi:10.1037/0012-1649.42.3.555

O'Neill, D. K. (1996). Two-year-old children's sensitivity to a parent's knowledge state when making requests. Child Development, 659-677.

Olsen-Fulero, L., \& Conforti, J. (1983). Child responsiveness to mother questions of varying type and presentation. Journal of Child Language, 10(03), 495-520.

Peters, A. M. (1990). The role of Imitation in the developing syntax of a blind child. Text \& Talk, 1(3), 311-312.

Pew Research Center. (2010). The new demography of american motherhood. Retrieved from http://www.pewsocialtrends.org/2010/05/06/the-new-demography-of-americanmotherhood/

Post, K. (1994). Negative evidence. In J. Sokolov \& C. Snow (Eds.), Handbook of research in language development using CHILDES (pp. 132-173). Hillsdale, NJ: Lawrence Erlbaum Associates.

Redfield, D. L., \& Rousseau, E. W. (1981). A meta-analysis of experimental research on teacher questioning behavior. Review of Educational Research, 51(2), 237-245. doi: $10.3102 / 00346543051002237$

Rowe, M. L., Coker, D., \& Pan, B. A. (2004). A comparison of fathers' and mothers' talk to toddlers in low-income families. Social Development, 13(2), 278-291.

Rowe, M. L., Leech, K. A., \& Cabrera, N. (2016). Going beyond input quantity: Wh-questions matter for toddlers' language and cognitive development. Cognitive Science.

Rowland, C. F., \& Fletcher, S. L. (2006). The effect of sampling on estimates of lexical specificity and error rates. Journal of Child Language, 33(4), 859-877. 
doi: $10.1017 / \mathrm{S} 0305000906007537$

Sachs, J. (1983). Talking about the there and then: The emergence of displaced reference in parent-child discourse. In K. E. Nelson (Ed.), Children's language (Vol. 4, pp. 1-28). Hillsdale, NJ: Lawrence Erlbaum Associates.

Sage, K. D., \& Baldwin, D. (2010). Social gating and pedagogy: Mechanisms for learning and implications for robotics. Neural Networks, 23(8), 1091-1098. doi:10.1016/j.neunet.2010.09.004

Searle, J. R. (1969). Speech acts: An essay in the philosophy of language. Cambridge: Cambridge university press.

Sénéchal, M. (1997). The differential effect of storybook reading on preschoolers' acquisition of expressive and receptive vocabulary. Journal of Child Language, 24(01), 123-138.

Shafto, P., Goodman, N. D., \& Frank, M. C. (2012). Learning from others: The consequences of psychological reasoning for human learning. Perspectives on Psychological Science, 7(4), 341-351. doi:10.1177/1745691612448481

Shafto, P., Goodman, N. D., \& Griffiths, T. L. (2014). A rational account of pedagogical reasoning: Teaching by, and learning from, examples. Cognitive Psychology, 71, 55-89. doi:10.1016/j.cogpsych.2013.12.004

Shatz, M. (1978). Children's comprehension of their mothers' question-directives. Journal of Child Language, 5(01), 39-46.

Shatz, M. (1979). How to do things by asking: Form-function pairings in mothers' questions and their relation to children's responses. Child Development, 1093-1099.

Shneidman, L., Gaskins, S., \& Woodward, A. (2015). Child-directed teaching and social learning at 18 months of age: evidence from Yucatec Mayan and US infants. Developmental 
science. doi:10.1111/desc. 12318

Shneidman, L., Gweon, H., Schulz, L. E., \& Woodward, A. L. (2016). Learning from others and spontaneous exploration: A cross-cultural investigation. Child Development, 87(3), 723735.

Siraj-Blatchford, I., \& Manni, L. (2008). 'Would you like to tidy up now?'An analysis of adult questioning in the English Foundation Stage. Early Years, 28(1), 5-22.

Snow, C. E. (1972). Mothers' speech to children learning language. Child Development, 549-565.

Snow, C. E. (1983). Literacy and language: Relationships during the preschool years. Harvard Educational Review, 53(2), 165-189. doi:10.17763/haer.53.2.t6177w39817w2861

Snow, C. E., Arlman-Rupp, A., Hassing, Y., Jobse, J., Joosten, J., \& Vorster, J. (1976). Mothers' speech in three social classes. Journal of Psycholinguistic Research, 5(1), 1-20. doi:10.1007/BF01067944

Stine, E. L., \& Bohannon, J. N. (1983). Imitations, interactions, and language acquisition. Journal of Child Language, 10(03), 589-603. doi:10.1017/S0305000900005389

Suppes, P. (1974). The semantics of children's language. American Psychologist, 29(2), 103. doi: $10.1037 / \mathrm{h} 0036026$

Theakston, A. L., Lieven, E. V., Pine, J. M., \& Rowland, C. F. (2001). The role of performance limitations in the acquisition of verb-argument structure: An alternative account. Journal of Child Language, 28(01), 127-152.

Tomasello, M. (1999). The cultural origins of human cognition. Cambridge, MA: Harvard University Press.

Topál, J., Gergely, G., Miklósi, Á., Erdőhegyi, Á., \& Csibra, G. (2008). Infants' perseverative search errors are induced by pragmatic misinterpretation. Science, 321(5897), 1831-1834. 
doi:10.1126/science. 1161437

Van Houten, L. J. (1986). The role of maternal input in the acquisition process: The communicative strategies of adolescent and older mothers with the language learning children. Paper presented at the Boston University Conference on Language Development, Boston.

Von Secker, C. (2002). Effects of inquiry-based teacher practices on science excellence and equity. The Journal of Educational Research, 95(3), 151-160. doi:10.2307/27542373

Vredenburgh, C., Kushnir, T., \& Casasola, M. (2014). Pedagogical cues encourage toddlers' transmission of recently demonstrated functions to unfamiliar adults. Developmental science, n/a-n/a. doi:10.1111/desc.12233

Walker, K., \& Armstrong, L. (1995). Do mothers and fathers interact differently with their child or is it the situation which matters? Child: Care, Health and Development, 21(3), 161181.

Warren-Leubecker, A., \& Bohannon III, J. N. (1984). Intonation patterns in child-directed speech: Mother-father differences. Child Development, 1379-1385. doi:10.2307/1130007

Weist, R. M., Pawlak, A., \& Hoffman, K. (2009). Finiteness systems and lexical aspect in child Polish and English. Linguistics, 47(6), 1321-1350. doi:10.1515/LING.2009.046

Weist, R. M., \& Zevenbergen, A. A. (2008). Autobiographical memory and past time reference. Language Learning and Development, 4(4), 291-308. doi:10.1080/15475440802293490

Wells, C. G. (1981). Learning through interaction: The study of language development. Cambridge, UK: Cambridge University Press.

Wilson, B., \& Peters, A. M. (1988). What are you cookin' on a hot?: Movement constraints in the speech of a three-year-old blind child. Language, 64(2), 249-273. 
Wilson, J., \& Henry, A. (1998). Parameter setting within a socially realistic linguistics. Language in Society, 27(01), 1-21. doi:10.1017/S0047404500019709

Wise, K. C., \& Okey, J. R. (1983). A meta-analysis of the effects of various science teaching strategies on achievement. Journal of Research in Science Teaching, 20(5), 419-435. doi:10.1002/tea.3660200506

Yu, Y., Landrum, A., Bonawitz, E., \& Shafto, P. (under review). Questioning supports effective transmission of knowledge and increased exploratory learning in pre-kindergarden children. 
Table 1

Descriptions of Transcripts Used in the Study

\begin{tabular}{|c|c|c|c|c|c|c|c|c|c|c|}
\hline Original study & $\begin{array}{l}\text { \# of mother- } \\
\text { child } \\
\text { conversations }\end{array}$ & $\begin{array}{l}\text { \# of father- } \\
\text { child } \\
\text { conversations }\end{array}$ & $\begin{array}{c}\text { Era of } \\
\text { data } \\
\text { collection }\end{array}$ & $\begin{array}{l}\text { Location } \\
\text { of data } \\
\text { collection }\end{array}$ & $\begin{array}{l}\text { Child's } \\
\text { age } \\
\text { (month) }\end{array}$ & $\begin{array}{l}\text { Child's } \\
\text { gender }\end{array}$ & $\begin{array}{l}\text { Family } \\
\text { SES }\end{array}$ & $\begin{array}{l}\text { Sampling and procedural } \\
\text { characteristics of the } \\
\text { recordings }\end{array}$ & $\begin{array}{l}\text { Average \# } \\
\text { of parent } \\
\text { sentences }\end{array}$ & $\begin{array}{l}\text { Average \# } \\
\text { of parent } \\
\text { questions }\end{array}$ \\
\hline $\begin{array}{l}\text { (Bohannon III \& } \\
\text { Marquis, 1977); (Stine } \\
\text { \& Bohannon, 1983) }\end{array}$ & 1 & 0 & $70 \mathrm{~s}$ & USA & 36 & $\mathrm{M}$ & NS & $\begin{array}{l}\text { Conversation between } \\
\text { mother and child, with } \\
\text { play materials available }\end{array}$ & 213 & 82 \\
\hline (Braunwald, 1976) & 1 & 0 & $70 \mathrm{~s}$ & USA & 37 & $\mathrm{~F}$ & NS & $\begin{array}{l}\text { Recordings during meal in } \\
\text { the researcher's home }\end{array}$ & 20 & 5 \\
\hline $\begin{array}{l}\text { (Demetras, 1986, } \\
\text { 1989) }\end{array}$ & 3 & 4 & $80 \mathrm{~s}$ & USA & $24-26$ & $4 \mathrm{M}$ & NS & $\begin{array}{l}\text { 20-minute recordings } \\
\text { during free play with toys }\end{array}$ & 319.3 & 150.1 \\
\hline $\begin{array}{l}\text { (Demetras, Post, \& } \\
\text { Snow, 1986; Post, } \\
\text { 1994) }\end{array}$ & 2 & 0 & $80 \mathrm{~s}$ & USA & $24-31$ & $2 \mathrm{~F}$ & $\begin{array}{l}\text { Working- } \\
\text { class }\end{array}$ & $\begin{array}{l}\text { Recordings during free } \\
\text { play with toys }\end{array}$ & 776.5 & 213.5 \\
\hline $\begin{array}{l}\text { (Demuth, Culbertson, } \\
\text { \& Alter, 2006) }\end{array}$ & 6 & 3 & $00 \mathrm{~s}$ & USA & $24-27$ & $3 \mathrm{M} 3 \mathrm{~F}$ & NS & $\begin{array}{l}\text { Recordings during } \\
\text { spontaneous interactions } \\
\text { at home }\end{array}$ & 479.2 & 131 \\
\hline $\begin{array}{l}\text { (Dickinson \& Tabors, } \\
\text { 2001) }\end{array}$ & 58 & 18 & $80 \mathrm{~s}$ & USA & $43-68$ & $\begin{array}{l}30 \mathrm{M} \\
28 \mathrm{~F}\end{array}$ & $\begin{array}{l}\text { Low- } \\
\text { income }\end{array}$ & $\begin{array}{l}\text { Typical mealtime } \\
\text { interactions }\end{array}$ & 153.9 & 51.7 \\
\hline (Gleason, 1980) & 13 & 13 & $70 \mathrm{~s}$ & USA & $32-62$ & $6 \mathrm{M} 7 \mathrm{~F}$ & NS & Conversations at dinner & 201.2 & 60.3 \\
\hline $\begin{array}{l}\text { (Hayes \& Ahrens, } \\
1988 \text { ) }\end{array}$ & 2 & 0 & $80 \mathrm{~s}$ & USA & $36-40$ & $1 \mathrm{M} 1 \mathrm{~F}$ & $\begin{array}{l}\text { Working- } \\
\text { class }\end{array}$ & $\begin{array}{l}\text { Samples of naturalistic } \\
\text { speech }\end{array}$ & 93 & 13.5 \\
\hline $\begin{array}{l}\text { (Henry, 1995; J. } \\
\text { Wilson \& Henry, } \\
\text { 1998) }\end{array}$ & 3 & 1 & $90 \mathrm{~s}$ & UK & $33-54$ & $2 \mathrm{M} 1 \mathrm{~F}$ & NS & $\begin{array}{l}\text { Recordings at mealtimes, } \\
\text { bedtime, bath time, etc. }\end{array}$ & 341 & 184 \\
\hline (Howe, 1981) & 12 & 0 & $70 \mathrm{~s}$ & UK & 24 & $7 \mathrm{M} 2 \mathrm{~F}$ & $\begin{array}{l}\text { Specified } \\
\text { for each } \\
\text { family }\end{array}$ & $\begin{array}{l}\text { Recordings while playing } \\
\text { with toys }\end{array}$ & 213 & 82 \\
\hline (Kuczaj, 1977) & 1 & 1 & $70 \mathrm{~s}$ & USA & 36 & $\mathrm{M}$ & NS & $\begin{array}{l}\text { 30-minute recording in the } \\
\text { researcher's home }\end{array}$ & 59 & 34.5 \\
\hline (Lieven, Salomo, \& & 1 & 0 & $00 \mathrm{~s}$ & UK & 36 & M & Middle- & 60 -minute recording & 1063 & 335 \\
\hline
\end{tabular}


Tomasello, 2009)

(MacWhinney, 2000)

(McCune \& Vihman,

1987)

(Nelson, 1989)

(Peters, 1990; B.

Wilson \& Peters,

1988)

(Rowland \& Fletcher

2006)

(Sachs, 1983)

(Snow, 1983)

(Suppes, 1974)

(Theakston, Lieven,

Pine, \& Rowland

2001)

(Van Houten, 1986)

(Warren-Leubecker \&

Bohannon III, 1984)

(Weist, Pawlak, \&

Hoffman, 2009; Weist

\& Zevenbergen, 2008)

(Wells, 1981)

Unpublished research

by Julie McMillan

\begin{tabular}{|c|c|c|c|c|c|c|c|c|c|}
\hline 0 & 1 & $80 \mathrm{~s}$ & USA & 30 & M & $\begin{array}{l}\text { class } \\
\text { NS }\end{array}$ & $\begin{array}{l}\text { during free play } \\
\text { Natural record of the } \\
\text { researcher's family } \\
\text { interactions }\end{array}$ & 58 & 23 \\
\hline 4 & 0 & $80 \mathrm{~s}$ & USA & 24 & $2 \mathrm{M} 2 \mathrm{~F}$ & NS & $\begin{array}{l}\text { Recordings during free } \\
\text { play with toys }\end{array}$ & 225.3 & 64 \\
\hline 0 & 1 & $80 \mathrm{~s}$ & USA & 24 & $\mathrm{~F}$ & NS & Bedtime conversation & 23 & 7 \\
\hline 0 & 1 & $80 \mathrm{~s}$ & USA & 24 & M & NS & $\begin{array}{l}\text { Conversation between the } \\
\text { researcher and his child }\end{array}$ & 251 & 39 \\
\hline 1 & 1 & $90 \mathrm{~s}$ & UK & 36 & $\mathrm{~F}$ & NS & $\begin{array}{l}\text { Recording during everyday } \\
\text { play activities }\end{array}$ & 365.5 & 68 \\
\hline 1 & 1 & $70 \mathrm{~s}$ & USA & 39 & $\mathrm{~F}$ & NS & $\begin{array}{l}\text { Conversations in the } \\
\text { researcher's home }\end{array}$ & 37 & 10.5 \\
\hline 1 & 1 & $70 \mathrm{~s}$ & USA & 30 & M & NS & $\begin{array}{l}\text { Conversations in the } \\
\text { researcher's home }\end{array}$ & 222.5 & 50.5 \\
\hline 1 & 1 & $70 \mathrm{~s}$ & USA & 36 & $\mathrm{~F}$ & NS & Naturalistic conversations & 369.5 & 209.5 \\
\hline 10 & 2 & $90 \mathrm{~s}$ & UK & $24-32$ & $5 \mathrm{M} 5 \mathrm{~F}$ & NS & $\begin{array}{l}\text { 30-minute recordings } \\
\text { during normal play } \\
\text { activities }\end{array}$ & 441.2 & 160.8 \\
\hline 20 & 0 & $80 \mathrm{~s}$ & USA & 28 & $13 \mathrm{M} 7 \mathrm{~F}$ & NS & $\begin{array}{l}\text { 3-minute interactions while } \\
\text { the child eats lunch }\end{array}$ & 35 & 11.9 \\
\hline 11 & 10 & $80 \mathrm{~s}$ & USA & $24-70$ & $6 \mathrm{M} \mathrm{5F}$ & $\begin{array}{l}\text { Middle- } \\
\text { class }\end{array}$ & $\begin{array}{l}\text { Conversation in the child's } \\
\text { home, with the child's } \\
\text { own toys or books present }\end{array}$ & 153.3 & 68.7 \\
\hline 1 & 0 & $00 \mathrm{~s}$ & USA & 38 & M & $\begin{array}{l}\text { Middle- } \\
\text { class }\end{array}$ & $\begin{array}{l}\text { 30-minute caregiver-child } \\
\text { interactions }\end{array}$ & 256 & 159 \\
\hline 11 & 4 & $70 \mathrm{~s}$ & UK & $26-60$ & $5 \mathrm{M} 7 \mathrm{~F}$ & NS & $\begin{array}{l}\text { Spontaneous conversation } \\
\text { without awareness of } \\
\text { being observed }\end{array}$ & 90.5 & 26 \\
\hline 1 & 0 & $00 \mathrm{~s}$ & USA & 28 & $\mathrm{~F}$ & NS & Naturalistic conversation & 59 & 26 \\
\hline
\end{tabular}

Note. SES = socioeconomic status; NS = not specified. 
Table 2

Coding Scheme for Categories and Subcategories of Questions, and Their Relative Distributions in Mother-child and Father-child

\section{Conversations}

\begin{tabular}{|c|c|c|c|c|}
\hline $\begin{array}{l}\text { Category / } \\
\text { subcategory }\end{array}$ & Description & Examples & $\begin{array}{l}\text { Proportion in } \\
\text { mother-child } \\
\text { questions }(S D)\end{array}$ & $\begin{array}{l}\text { Proportion in } \\
\text { father-child } \\
\text { questions }(S D)\end{array}$ \\
\hline \multirow{2}{*}{$\begin{array}{c}\text { Pedagogical } \\
\text { Generic }\end{array}$} & Questioner knows the answer, wants questionee to learn & - & $27 \%(25 \%)$ & $31 \%(30 \%)$ \\
\hline & $\begin{array}{l}\text { Teaching about kinds of objects or people, general } \\
\text { concepts, rules, or scripts }\end{array}$ & $\begin{array}{l}\text { "What's 'A' stand for?"; "What would } \\
\text { you say [in this situation]?" }\end{array}$ & $3 \%(13 \%)$ & $3 \%(18 \%)$ \\
\hline Specific & Teaching about a specific object, event, or person & $\begin{array}{l}\text { "What's that?"; "What does this } \\
\text { button do?" }\end{array}$ & $24 \%(24 \%)$ & $28 \%(27 \%)$ \\
\hline \multicolumn{2}{|c|}{ Information-seeking Questioner seeks answer from questionee } & - & \multirow{3}{*}{$\begin{array}{l}60 \%(26 \%) \\
28 \%(23 \%)^{*} \\
24 \%(22 \%)^{\dagger}\end{array}$} & \multirow{3}{*}{$\begin{array}{l}60 \%(28 \%) \\
35 \%(24 \%)^{*} \\
18 \%(20 \%)^{\dagger}\end{array}$} \\
\hline Specific & Asking about a specific object, event, or person & "What did you do at school?" & & \\
\hline Check status & $\begin{array}{l}\text { Asking about the child's needs, opinions, or } \\
\text { physical/emotional/epistemic status }\end{array}$ & $\begin{array}{l}\text { "Are you hungry?"; "Do you } \\
\text { remember?" }\end{array}$ & & \\
\hline Clarification & Asking the child to repeat what he/she just said & "You what?”; "Huh?” & $7 \%(10 \%)$ & $5 \%(9 \%)$ \\
\hline Permission & Asking for permission & "Can I get you changed?" & $1 \%(4 \%)$ & $1 \%(5 \%)$ \\
\hline Rhetorical & Questions not intended to be answered verbally & - & $13 \%(15 \%)^{*}$ & $9 \%(11 \%)^{*}$ \\
\hline Commands & Giving commands in a question form & "Why don't you help clean up?" & $8 \%(12 \%)^{* * *}$ & $3 \%(8 \%)^{* * *}$ \\
\hline Attention & Raising child's attention with a question & "Well?"; "Jack?" & $5 \%(8 \%)$ & $6 \%(9 \%)$ \\
\hline
\end{tabular}

Note. Asterisks denote significant differences between mother-child and father-child questions, ${ }^{\dagger} p<.1 ;{ }^{*} p<.05 ;{ }^{* * *} p<.001$. 
Table 3

Fixed and Random Effects for Models Predicting the Proportion of Pedagogical Questions

\begin{tabular}{|c|c|c|c|c|c|c|c|c|}
\hline & \multicolumn{4}{|c|}{ Model 1} & \multicolumn{4}{|c|}{ Model 2} \\
\hline & Estimate & $S E$ & $p$ & VIF & Estimate & $S E$ & $p$ & VIF \\
\hline Intercept & .13 & .15 & .41 & - & .20 & .13 & .12 & - \\
\hline \multicolumn{9}{|l|}{$\begin{array}{l}\text { Fixed effects }(B) \text { on conversation } \\
\text { level }\end{array}$} \\
\hline Parent's gender (male - female) & -.004 & .041 & .93 & 1.36 & & & & \\
\hline Child's age & -.004 & .002 & $.022^{*}$ & 1.81 & -.004 & .002 & $.038^{*}$ & 1.36 \\
\hline \multicolumn{9}{|l|}{ Context } \\
\hline Free play - daily routine & .088 & .074 & .24 & 4.53 & & & & \\
\hline Mealtime - daily routine & .087 & .087 & .33 & 4.83 & & & & \\
\hline Other parent (present - absent) & .045 & .042 & .29 & 1.56 & & & & \\
\hline Sibling (present - absent) & -.028 & .041 & .50 & 1.49 & & & & \\
\hline \multicolumn{9}{|l|}{ Fixed effects $(B)$ on child level } \\
\hline Child's gender (male - female) & .045 & .032 & .16 & 1.04 & & & & \\
\hline \multicolumn{9}{|l|}{ Family SES } \\
\hline Middle-class - working-class & .224 & .088 & $.015^{*}$ & 2.07 & .261 & .081 & $.003^{* *}$ & 1.22 \\
\hline Not specified - working-class & .020 & .077 & .80 & 1.87 & .000 & .070 & 1.00 & 1.56 \\
\hline \multicolumn{9}{|l|}{ Fixed effects $(B)$ on study level } \\
\hline Time of data collection & .069 & .032 & $.045^{*}$ & 1.22 & .063 & .028 & $.038^{*}$ & 1.03 \\
\hline Location (UK - USA) & .005 & .073 & .95 & 1.65 & & & & \\
\hline \# of children included & -.018 & .033 & .58 & & & & & \\
\hline $\begin{array}{l}\text { Sampling (random sample - } \\
\text { convenience sample) }\end{array}$ & .011 & .112 & .92 & & & & & \\
\hline Random effect $\left(\sigma^{2}\right)$ on study & .009 & .007 & .21 & - & .007 & .006 & .35 & - \\
\hline-2 restricted log likelihood & \multicolumn{4}{|c|}{44.3} & \multicolumn{4}{|c|}{20.2} \\
\hline BIC & \multicolumn{4}{|c|}{55.1} & \multicolumn{4}{|c|}{31.0} \\
\hline
\end{tabular}

Note. The restricted maximum likelihood (REML) method was used for parameter estimation. $S E=$ standard error; VIF = Variance Inflation Factor; SES = socioeconomic status; BIC $=$ Schwarz's Bayesian Information Criterion. ${ }^{*} p<.05 ;{ }^{* *} p<.01$. 


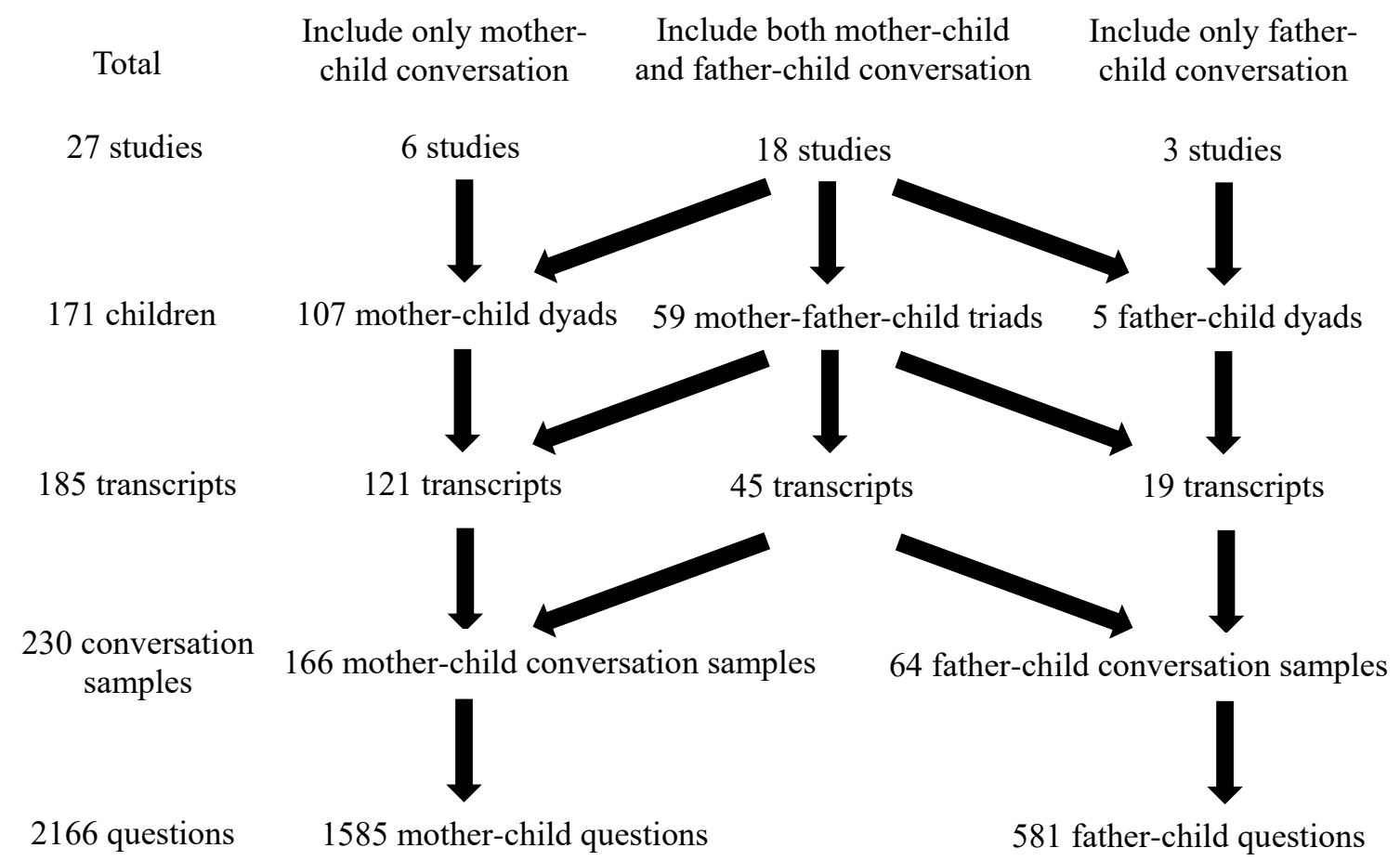

Figure 1. Samples used for analysis. We included 166 mother-child conversation samples and 64 father-child conversation samples from 185 transcripts that represent day-to-day family conversations at home. To ensure independent sampling, only one conversation sample is included for each mother-child and father-child dyad. For each conversation sample, two coders coded the first 10 questions from the parent to the child. If there was less than 10 questions in the sample (this is true for $13 \%$ of all samples), all questions were coded. Conversation samples with less than 3 questions were excluded. 


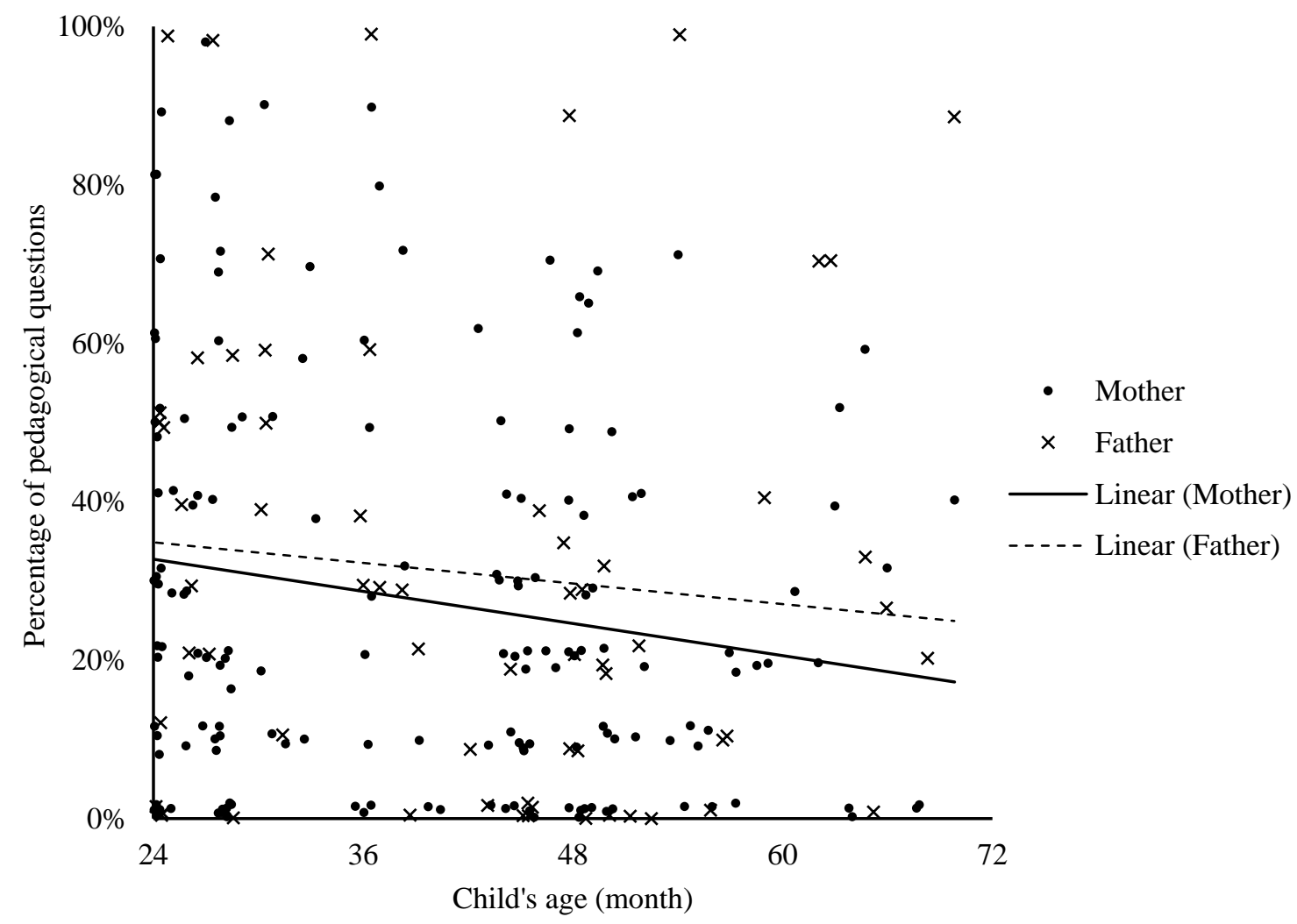

Figure 2. Proportion of parents' pedagogical questions decreased with child's age, $B=$ $.004, p=.038$. When data were separated by parents' gender, this trend was significant for mothers, $B=-.005, p=.009$, but not for fathers, $B=.001, p=.085$. Possible heteroscedasticity (unequal variabilities in parents' pedagogical questions as a function of child's age) was ruled out by further analyses (details see Supplementary Material). Data points have been jittered along both $\mathrm{x}$ axis (within \pm 0.5 month) and $\mathrm{y}$ axis (within $\pm 2 \%$ ) to improve readability. 


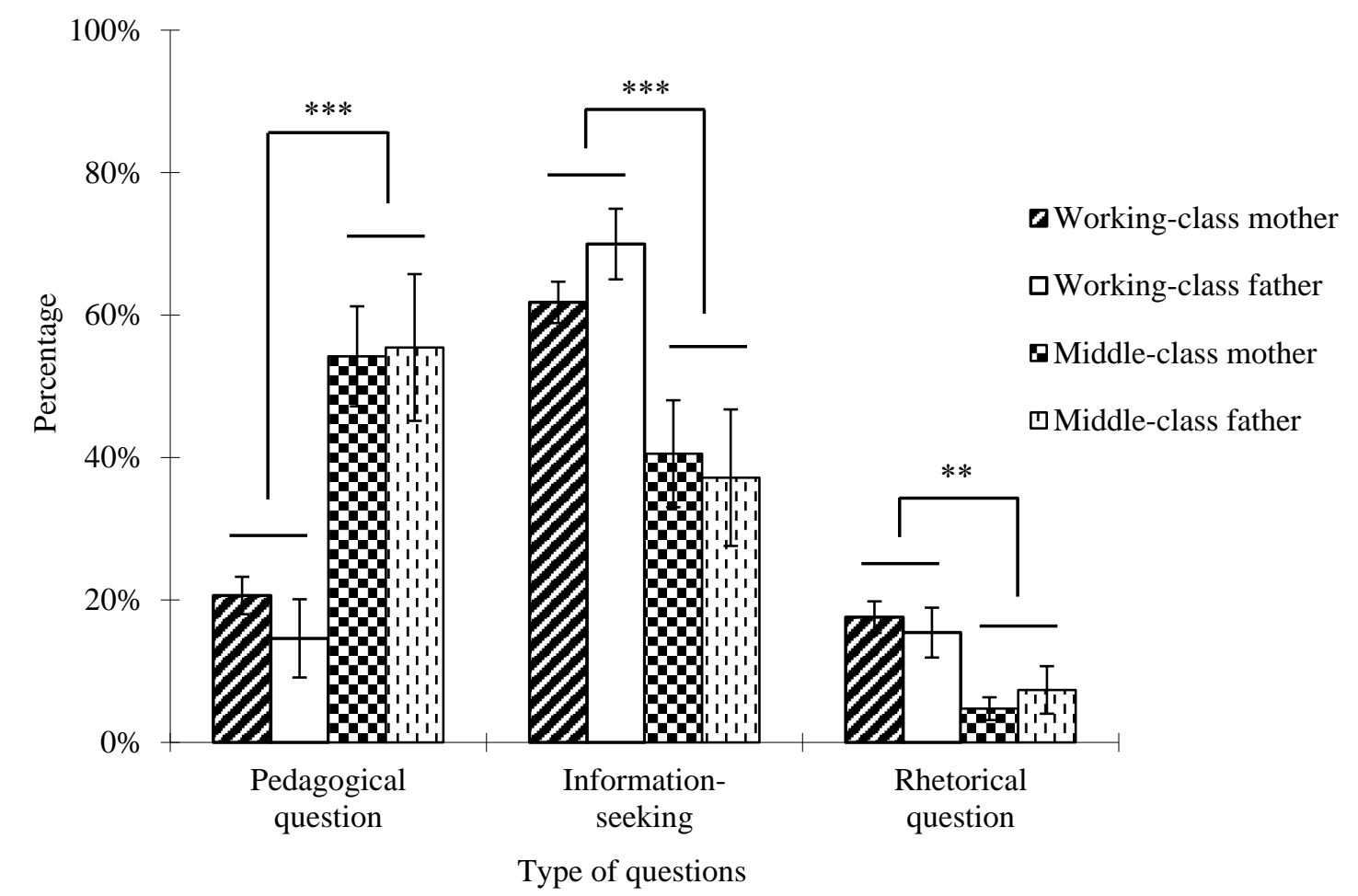

Figure 3. Parents from middle-class families asked more pedagogical questions, fewer information-seeking questions, and fewer rhetorical questions than parents from workingclass families, $p s<.01$. When data were separated by parents' gender, these differences were significant for both mothers and fathers, $p$ s $<.02$. Further analyses showed that for studies that recruited both working-class and middle-class families, the SES effects on questioning were also observed within studies (details see Supplementary Material). Error bars denote SE. ${ }^{* *} p<.01 ;{ }^{* * *} p<.001$. 


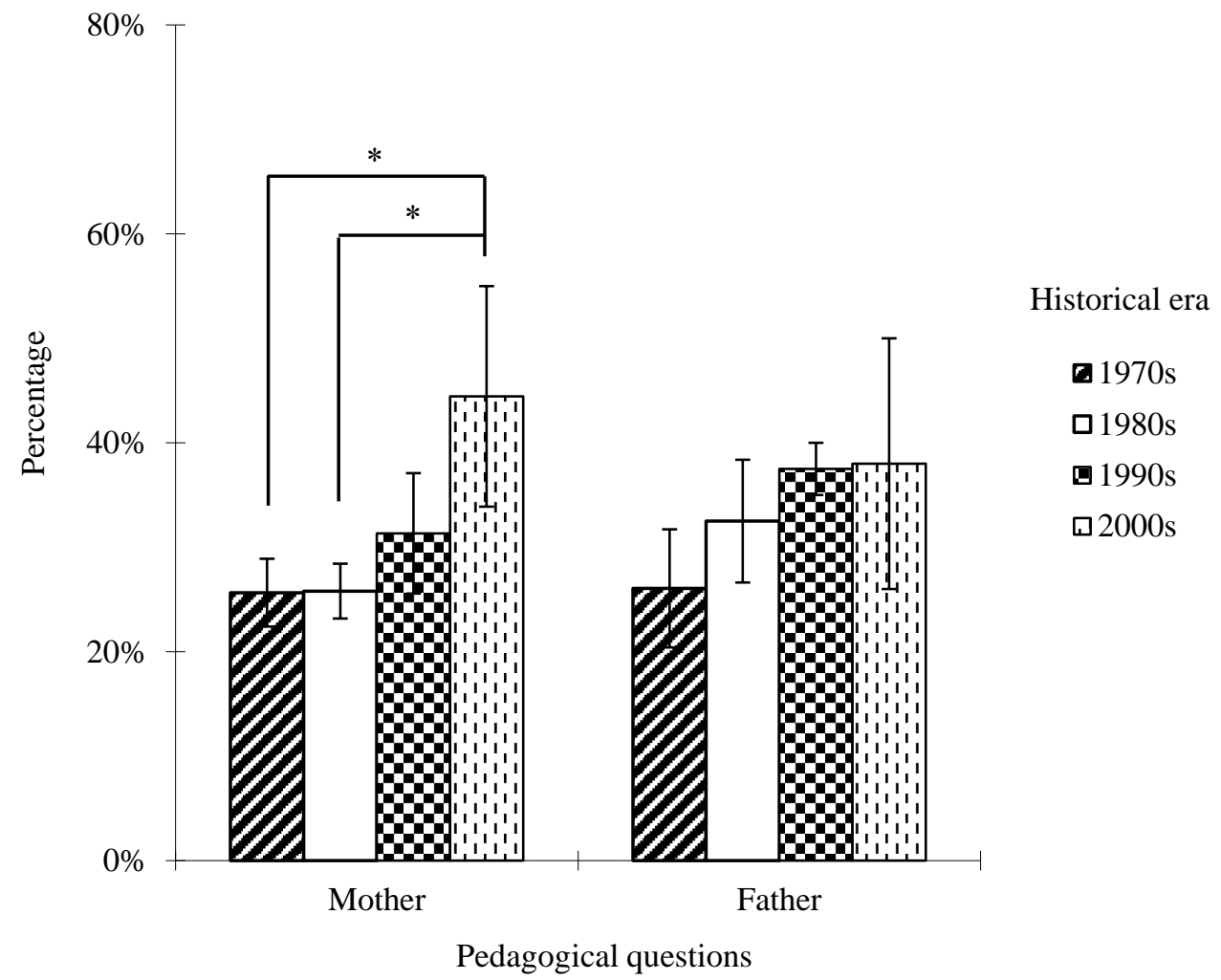

Figure 4. Parents' pedagogical questions increased with historical era, $B=.063, p=.038$.

When data were separated by parents' gender, mothers' pedagogical questions increased significantly with historical era, $B=.054, p=.049$, with mothers from the 2000s asking a higher proportion of pedagogical questions than mothers from the 1970s and 1980s, $t \mathrm{~s}>$ $2, p \mathrm{~s}<.05, d \mathrm{~s}>0.7$. The increasing trend of fathers' pedagogical questions along historical era was not statistically significant, $B=.045, p=.12$. Error bars denote SE. ${ }^{*} p$ $<.05$. 


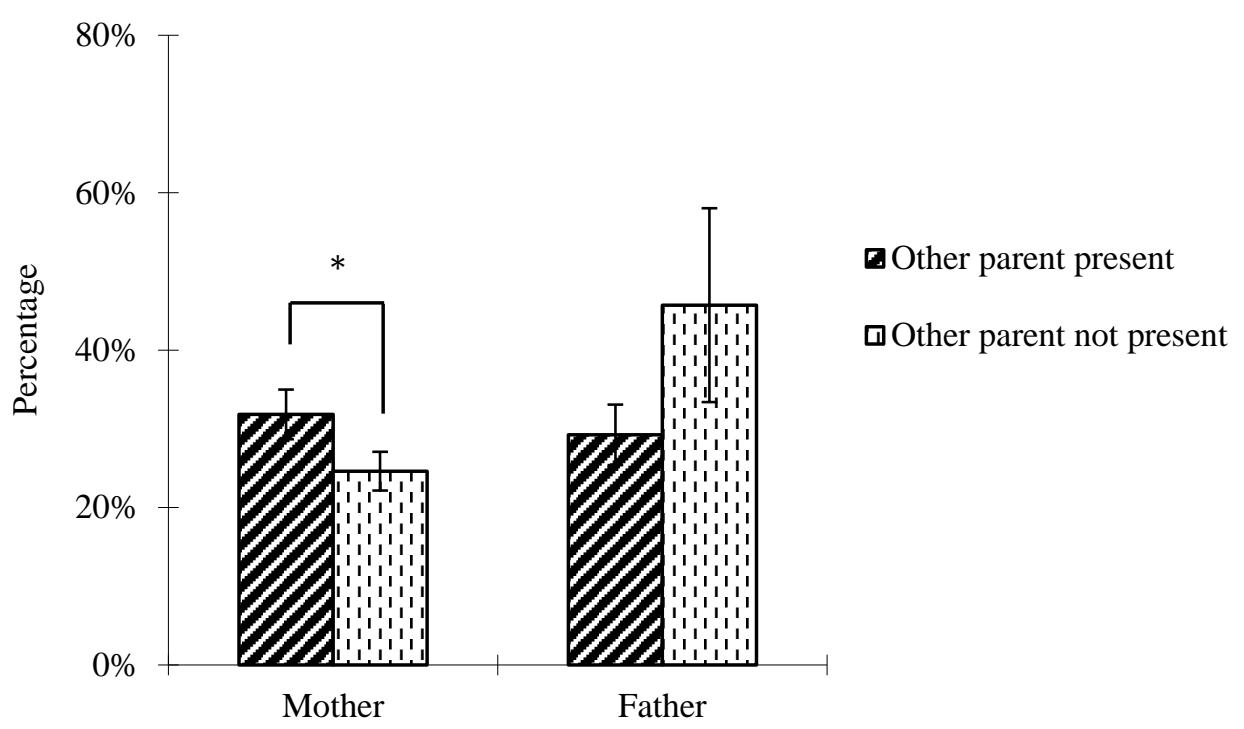

Pedagogical questions

Figure 5. An interaction effect between parents' gender and the presence of other parent was observed for the proportion of pedagogical questions, $F(1,226)=4.36, p=.038$. Mothers asked a higher proportion of pedagogical questions when the father was noted as present during the conversation, as compared to when the father was not noted as present, $B=.083, p=.045$. Fathers' pedagogical questions did not differ significantly based on mothers' presence, $B=-.172, p=.17$. This non-significant result may be due to a small but variable sample of father-child conversation when a mother is absent $(n=19)$. Error bars denote SE. ${ }^{*} p<.05$. 